\title{
浮遊型海洋構造物の方向スペクトル波中実験 に基く方向周波数応答関数推定（その3)
}

\author{
正員 竹 沢 誠 二* 正員 平 山次 清* \\ 正員上 野 誠 也* 正員陳 剛*
}

Estimation of directional frequency response functions of a floating offshore structure based on experiments in directional spectrum waves (3rd report)

\author{
by Seiji Takezawa Member Tsugukiyo Hirayama Member \\ Seiya Ueno Member Chen Gan Member
}

\begin{abstract}
Summary
Estimation of directional frequency transfer functions of floating offshore structures is important to estimate their behaviours in realistic short crested irregular waves (such waves are called as directional spectrum waves).

Of course, there are some theoretical calculation methods for such directional response functions, but it seems that there are not so many experimental results confirming such theoretical ones. For that purpose, square basins are needed.

In two previous reports, the authors showed the inverse estimation of directional transfer functions of a floating offshore structure only using results of a few experiments in directional spectrum waves in a long towing tank.

The response functions of wave exciting forces are treated in this paper. The precisions of estimated directional frequency response functions are confirmed using theoretical data.
\end{abstract}

\section{1. 緒言}

短波頂不規則波である海洋波中での浮体の動的応答を推 定することは非常に重要である。その推定のために波浪と 浮体に作用する波強制力の関係を表わす応答関数の果たす 役割は大きく，それを求めることは必要である。その応答 関数は, 波の入射角と波の周波数の 2 種類の独立変数で表 わされる方向周波数応答関数となる。

方向周波数応答関数は, 従来から理論的立場から求める 方法が提案されているが，それらを実験により確認してい る例は多くない ${ }^{3-5)}$ 。方向応答関数は, 入射角の異なる長波 頂波中の実測を多数繰り返すことにより, 角度ベースで求 めることができるが, そのためには角水槽等の設備が必要 となり，実験量も多くなる。

著者らは, 前報1)2 において方向波中の運動計測のみを用 いて波周波数領域での, すなわち線形 1 次応答としての浮 体運動の方向周波数応答関数を推定する手法を提案した。

* 横浜国立大学工学部
これは，長水槽において多分割造波装置を用いた方向スぺ クトル波の造波を行い, 半潜水型海洋構造物の運動等の計 測を実施し，そのデー夕のみから推定する手法である。方 向スペクトル波の造波により，構造物の 1 次元の運動応答 スペクトルと入射した方向波の 2 次元スペクトルが実測さ れ，それらを数種組み合わせることにより, 2 次元の方向周 波数応答関数が推定された。理論値を一部使用する文献 6) と異なり, 実測デー夕のみによる手法であり, 実機にも直 ちに適用可能である。

本報では波浪の浮体に作用する波強制力について，その 方向周波数応答関数を推定することを試みる。推定の原理 は前報と同様であり，これにより浮体の任意の方向周波数 応答関数が推定可能であることを示す。波強制力も運動と 同じく，自明な応答関数值が存在する波向角が存在する場 合にはそれを拘束条件として利用し, 精度を高めている。 また, 長波頂波の応答関数值が計測可能な波向角に対して も同様に拘束条件として扱っている。さらに，本報では， 理論的な波の方向スペクトル関数と仮定した方向周波数応 答関数を用いて計算された波強制力スペクトルデータを用 
いて方向周波数応答関数を推定し, 計算精度を確認した。 それを用いて, 計算精度の改善に関する検討を加えた。さ らに波強制力の有義值に方向スペクトル波の方向分布及び 波主方向が及ぼす影響を調べた。

\section{2. 推 定 方 法}

本報で提案する方向周波数応答関数の推定手法について 概略を説明する。詳細は前報1に記述されているので,ここ では改良点を中心に概略の説明にとどめる。まず，波によ る浮体の線形波強制力のスペクトルは次式で与えられる。

$$
S(\dot{\omega})=\int_{-\pi}^{\pi} W(\omega, \chi)|H(\omega, \chi)|^{2} d \chi
$$

$S$ は 1 次元波強制力スペクトルであり, $W$ は方向波のスペ クトル関数, $H$ は浮体の方向周波数応答関数である。 $\omega$ は 周波数, $\chi$ は浮体の $x$ 軸正方向を 0 度（従って, 向い波は $\left.180^{\circ}\right)$ とする波向角である。方向波を用いた水槽実験では, 浮体の波強制力スペクトル $S(\omega)$ と方向波スペクトル $W(\omega, \chi)$ が計測される。著者らが提案する方法は, これら のデータを用いて方向周波数応答関数の振幅比部分の $|H(\omega, \chi)|$ を逆算するものである。

推算の基本原理は，応答関数の二乗值を周波数毎に波向 角に関するフーリエ級数に展開し, 実験データからその係 数を最小二乗法により求めるものである。当然ながら, フ 一リエ係数は周波数の関数として与えられ，方向周波数応 答関数の振幅は次式で与えられる。

$$
|H(\omega, \chi)|^{2}=\sum_{k=0}^{\infty} a_{k}(\omega) \cos k \chi
$$

構造物の対称性を有効に利用すれば，応答関数は波向角の 偶関数になる。従って, $\cos$ 項のみの展開が可能である。波 向角に関しての周期は $2 \pi$ とし, 広い波向角範囲での応答 関数を求めることを目的とした一般性を持たせている。

推算は離散化して有限区間の周波数範囲で行っている。 周波数は使用した波のスペクトルから浮体への波強制力を 励起するパワーの存在する範囲を選び, 等間隔に分割した。 フーリエ級数の項数は全体の傾向が変化しない範囲の中か ら最小のものを選んだ。これは, 単に計算量の減少を目的 とするものだけでなく, 項数が多いと波向角に対し振動的 な応答関数が得られる傾向があるためである。

推算で求めるフーリエ級数は, 2 次元の行列要素で表わ される。しかし, 周波数に対しては独立であるから, ある 周波数 $\omega_{i}$ に対しては 1 次元のべクトル $\left(a_{k}\right)_{i}$ で記述でき る。式 (1)（2）を離散化し, 行列形式で表わせば, 次式と なる。

$$
\widehat{s}_{i}=\left(w_{i}\right)^{t}[C](a)_{i} \delta \chi
$$

添え字 $i$ は $\omega_{i}$ における值を意味し， $\widehat{s}_{i}$ はスカラーの応答 スペクトルの推定值, $w_{i}$ は 1 次元の波のスペクトル, $[C]$ は次式で与えられる行列である。

$$
[C]=\left[\begin{array}{cccc}
1 & \cos x_{1} & \cdots & \cos N x_{1} \\
1 & \cos \chi_{2} & \cdots & \cos N x_{2} \\
\vdots & \vdots & \ddots & \vdots \\
1 & \cos x_{n} & \cdots & \cos N x_{n}
\end{array}\right]
$$

実測值の応答スペクトルとの誤差を最小とするように, 異 なる波スペクトルを複数使用して $a_{k}$ を最小二乗法により 求める。

さらに, 推定精度を高めるために, 長波頂波による応答 関数の実測值があるものはこれも使用した。このデー夕は, 著者らの方向スペクトル造波機が長水槽の短辺に設置され たものであるため, 方向波の波の主方向と同一方向の長波 頂波を用いることになるが，これは狭い方向分布の極限値 の波とみなすこともできる。この実測值を推定応答関数が 満足するように拘束した。また, $y$ 軸方向の波に対してはサ ージ方向に波強制力が発生しないような自明の理論値を拘 束点データとして用いた。これらの拘束を追加することに より, 最小とすべき関数は推定誤差を $\varepsilon$ とれば, 次式で 与えられる。

$$
\left(\varepsilon^{2}\right)^{\prime}=\varepsilon^{2}+\sum_{p=1}^{P} \lambda_{p}\left((c)_{l}(a)_{i}-\left(\left|h_{i}\right|^{2}\right)_{l}\right)
$$

$\chi_{\iota}$ が $p$ 番目の拘束条件を与えられた波向角となるよう に $l$ が定められるものとする。 数である。この関数を最小とする条件から $\left(a_{k}\right)_{i}$ と $\lambda_{l}$ の連 立方程式が導かれ, 前報と同様に一般化逆行列を用いて解 が求められる7)。このように拘束条件を複数使用する改良 を加えて, 前報の推算より精度を高めた推定值を得ること を可能とした。

\section{3. 実験}

本報の推定で使用した実測データの計測実験に関して説 明する。

使用した半潜水型海洋構造物モデルは SR 192 で使用さ れたものと同一であり，2本ロワーハルと 8 本コラムの形 状である。モデルは $1 / 64$ スケールであり，ロワーハル長は $1.80 \mathrm{~m}, 2$ 本の中心線間の間隔は $0.94 \mathrm{~m}$ で $x$ 軸に平行に 取り付けられている。実験に使用した水槽は横浜国立大学 内の長水槽であり，モデルは計測用台車の下部に検力計を 介して取り付けられ，運動が拘束されている。モデルの設 置状況を図 1 に示す。長水槽の一端に多分割造波装置が設 置されており，壁面の反射を有効に利用して方向波を造波 することを可能としている8 。方向波の主方向は水槽の長 手方向と一致するため, 図 1 の設置条件は波向角は $180^{\circ}$ (向い波)となる場合である。検力計の剛性が高いため, 構 造物の運動は無視できる範曲である。また, 固有振動数が 本報で示す応答関数の周波数帯より高いため微小レベルで 運動が発生しても推算結果に影響を及ぼさないと考えられ る。

構造物に作用する波強制力の計測はこの検力計を用い 
た。検力計は，ヒーブとサージ方向の力とピッチ軸回りの モーメントを計測するように設置されている。検力計の計 測点は, 構造物重心から $z$ 軸方向に離れているため, 以下 の解析では重心点での波強制力値に換算して用いている。

使用した方向スペクトル波の計測解析されたスペクトル を図 2-a に示す。図中には平均周期の異なる 5 種類の波の データが示されている。データのスケールはすべて実機ス ケールに換算されている。図 2-bには，方向分布関数の平 均值が示されている。波の主方向を中心に対称型であり, $\cos ^{2}$ 分布と類似した形である。1 回の造波により広範囲の 角度からの波の入射を期待するために，このような広い分 布特性を持つ波を使用した。なお，方向分布関数は周波数

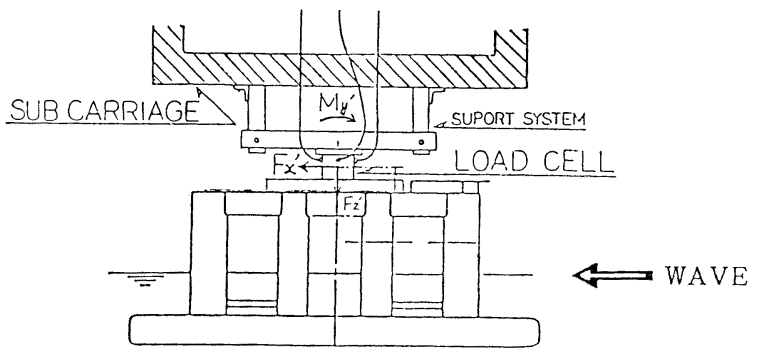

Fig. 1 Configuration of experiments

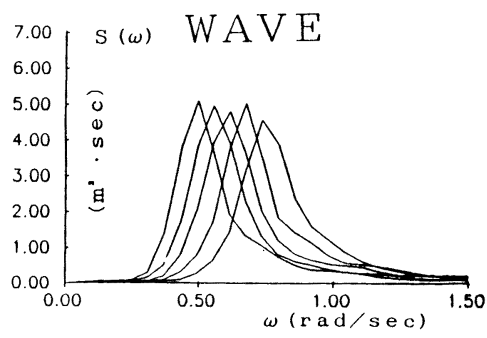

Fig. 2-a Spectral functions of directional waves measured by experiments

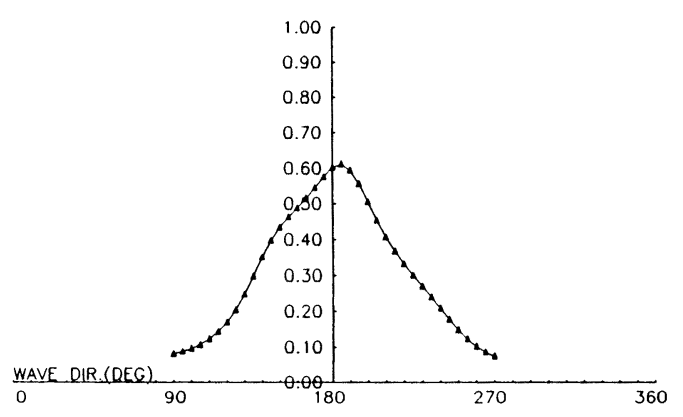

Fig. 2-b Mean directional distribution functions of wave measured by experiments
に対する平均值を正規化している。次章で使用する波はす べてこの分布をなす波である。

波の計測には，非接触型の計測システムを使用した。水 没させた光源から発射されたレーザービームを水面上から カメラで測定する方式を採用した。詳細な計測原理等は文 献 9 に記述されている。

方向波の造波は約 10 分間行い, 波の特性が均等化された 区間のデータのみを使用して解析した。取得デー夕はすべ てアナログ信号であるが，サンプリング周期 0.1 秒で $\mathrm{AD}$ 変換し, パーソナルコンピュータで記録し，解析等もデジ タル処理で行った。これらの解析条件は前報と同一である。

\section{4. 波強制力の方向周波数応答関数推定}

本章では，実測された波強制力のスペクトルと実測され た波の方向スペクトルから, 構造物の持つ方向周波数応答 関数を推算した結果を示す。実験に使用した波は図 2-aに 示す平均周期 7.3 秒 (実機換算) から 10.4 秒までの 5 種類 のスペクトルを持つ波である。いずれも，波の主方向を中 心に図 2-bに示す比較的広い方向分布を持つ波であり，波 の主方向が $x$ 軸と一致する向い波状態での実験データを 用いた。波の実測された方向分布関数は周波数によってば らつきが見られる。これを推算に用いたが, 図 2-bに示す 平均值と大きな差はない。方向スペクトル波の実験データ は 5 回だけの計測であるが,さらに精度を上げるために, 向い波の長波頂過渡水波の実験を 1 回追加している。この ように実験回数が少なくても良い精度で推算できる点が本 手法の特長である。

サージ波強制力の方向周波数応答関数の推算結果を図 3 に示す。実線は理論計算による応答関数であり，*印の付 いた線は実測データに基づく推算結果である。推算には 3 方向の拘束条件を含めている。 $90^{\circ}$ と $270^{\circ}$ はサージ波強制 力の発生しない方向であるから, 応答関数值を 0 に指定し, $180^{\circ}$ の向い波状態では長波頂過渡水波による実測值を満 足させている。波のパワーの少ない高周波領域と波の主方 向から離れた領域（横波付近）では理論值との差がみられ るが, 波のパワーが大きく構造物に影響の与える領域では 関数の形状が非常に良い一致を見せている。

図 4 にヒーブ波強制力の方向周波数応答関数を示す。推 算に用いた拘束条件は $180^{\circ}$ の 1 点のみである。使用した波 の主方向が向い波状態だけであるので, $90^{\circ}$ ( $270^{\circ} も$ 同様) 付近における推定精度は低いと考えられる。推算に使用し た一般化逆行列の性質により，この領域においては，推算 結果は真の值よりも低い值をとる傾向を持つ。この点を除 けば理論値との比較は良い一致が確認できる。

ピッチ波強制モーメントの推算結果を図 5 に示す。拘束 条件はサージの場合と同じく 3 点である。低周波領域では 関数の形状は似た傾向を示しているが，定量的な差が生じ ている。高周波領域では関数の形状も理論值と異なること 


\section{SURGE EXCITING FORCE}
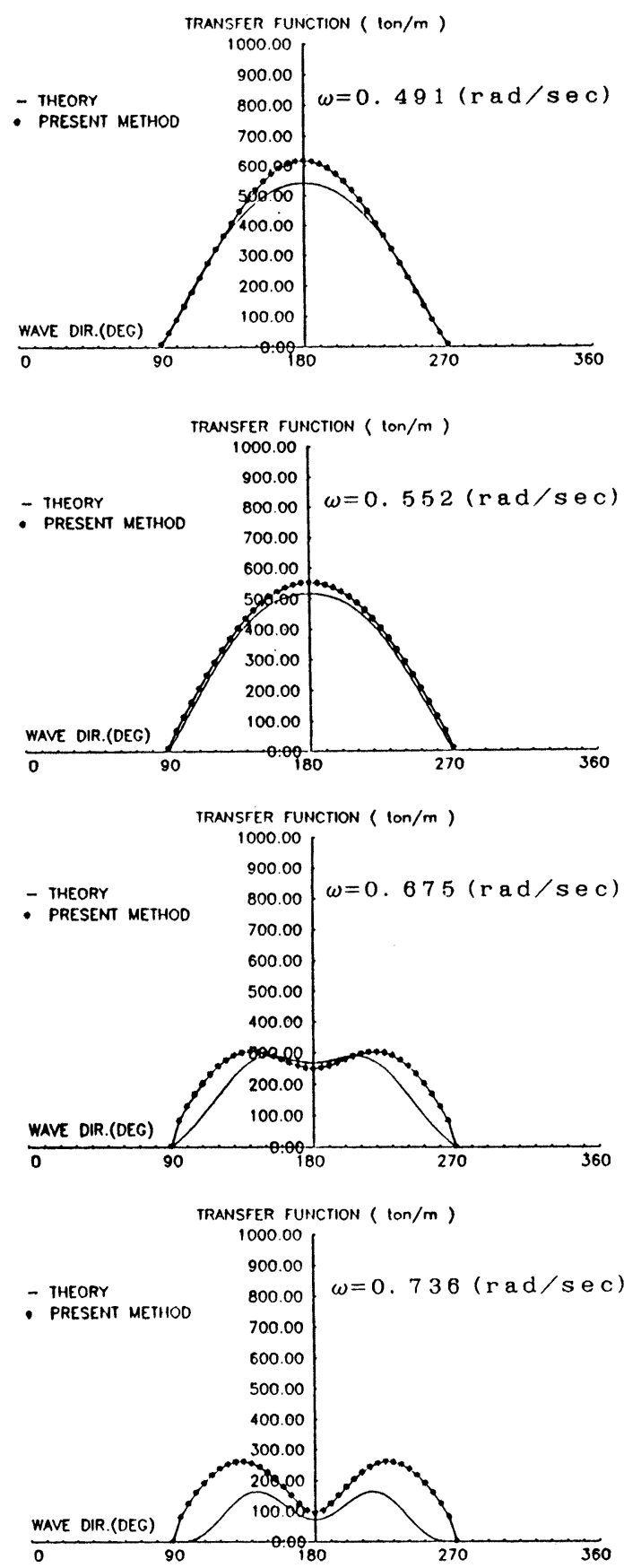

Fig. 3 Directional distribution of transfer functions of surge wave exciting forces (The experimental datum were used in the present method)
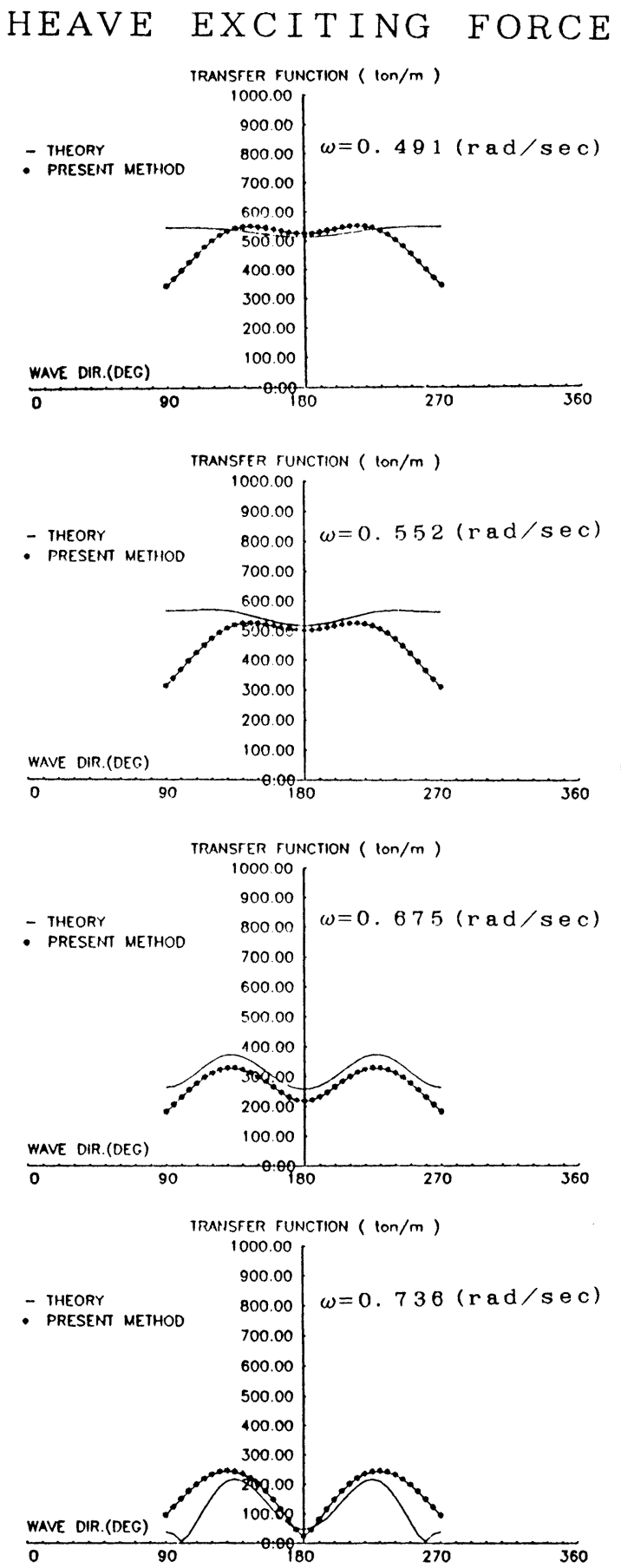

Fig. 4 Directional distribution of transfer functions of heave wave exciting forces (The experimental datum were used in the present method) 


\section{PI TCH EXCI T ING MOMENT}
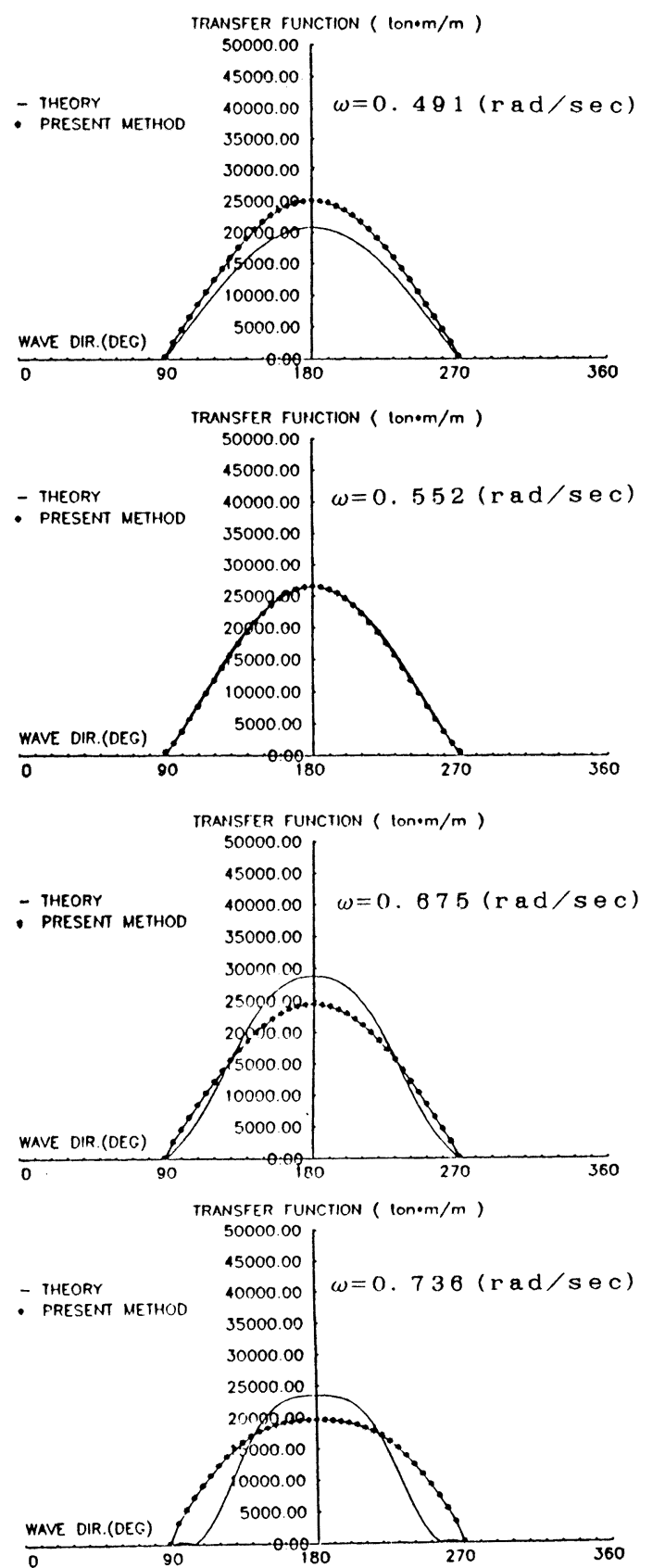

Fig. 5 Directional distribution of transfer functions of pitch wave exciting moments (The experimental datum were used in the present method)
が示されている。計算精度については次章で検討を加える が，本手法の精度が高いことが示される。

\section{5. 推定結果の検証}

\section{1 理論計算データによる推算}

本章では推算された方向周波数応答関数の精度に関する 検討を行う。前章では実測されたデー夕を用いて推算した 結果を示したが，その精度に関しては真の応答関数が未知 であるため確かなことが言えなかった。そこで，仮定した 波スペクトルと応答関数を用いて数值計算により算出した 波強制力のスペクトルデータから本手法により応答関数を 推算し，仮定した応答関数と比較して計算精度の検討を示 す。

計算に使用した波のスペクトルと方向分布関数を図 6 に 示す。前章で計測された波とほほ同一の特性を持つ波であ る。スペクトルは JONSWAP 型, 方向分布関数は $\cos ^{2}$ 分 布である。波強制力のスペクトルはこの波と理論值の方向 周波数応答関数とを用いて算出した。

推算結果を図 7 9 亿示す。前章同様に, 実線は理論值, *印の付いた線は推算結果である。計算精度が高ければ両 者は一致することから，計算結果の信頼性が示されている 図である。尚，推算には $180^{\circ}$ における理論値を拘束条件と して用いている。

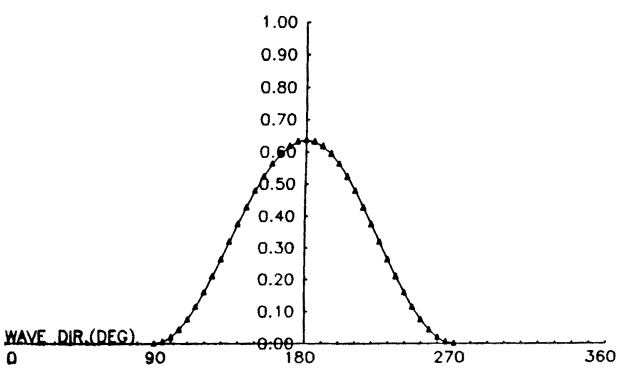

Fig. 6-b Mean directional distribution functions of wave (Theoretical values)

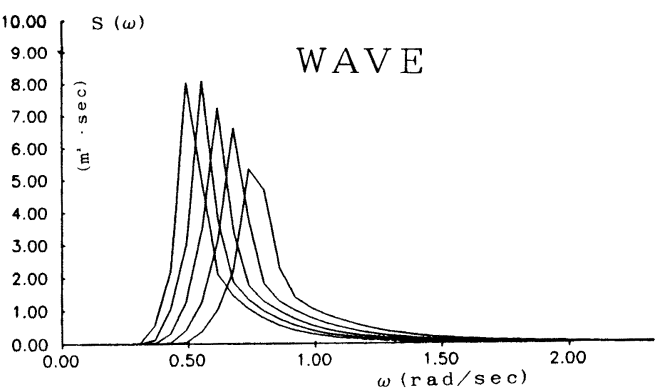

Fig. 6-a Spectral functions of directional waves (Theoretical values) 


\section{SURGE EXCITING FORCE}
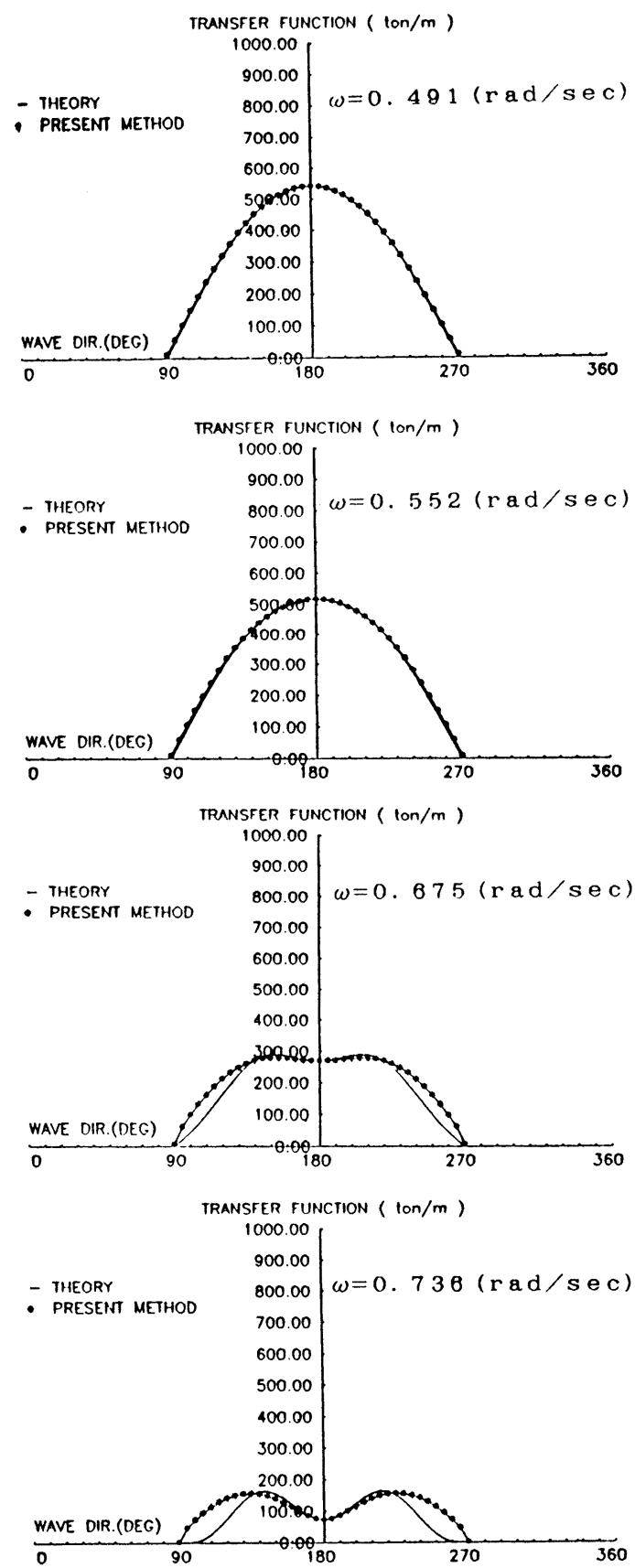

Fig. 7 Directional distribution of transfer functions of surge wave exciting forces (The theoretical values were used in the present method, direction of wave is $180^{\circ}$, constraint points are $90^{\circ}$ and $180^{\circ}$.)
HEAVE EXCITING FORCE
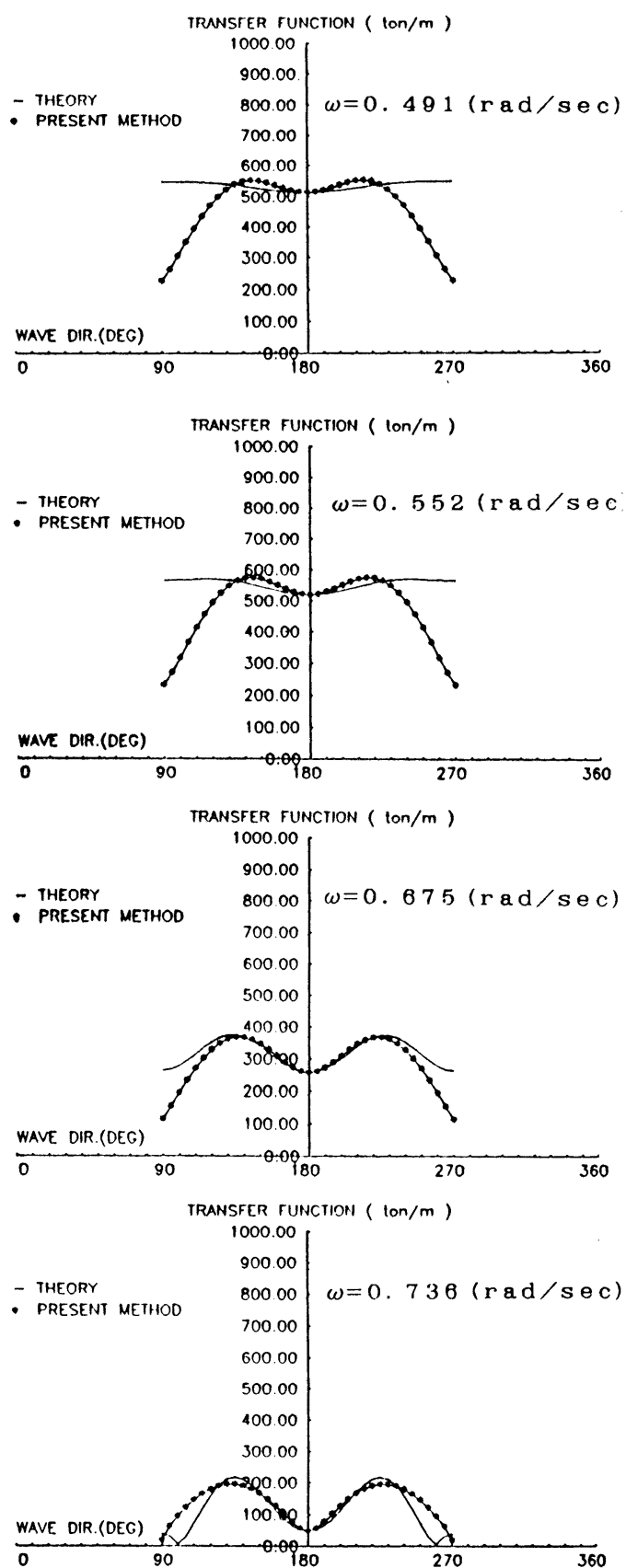

Fig. 8 Directional distribution of transfer functions of heave wave exciting forces (The theoretical values were used in the present method, direction of wave is $180^{\circ}$, constraint point is $180^{\circ}$.) 


\section{PITCH EXCITING MOMENT}
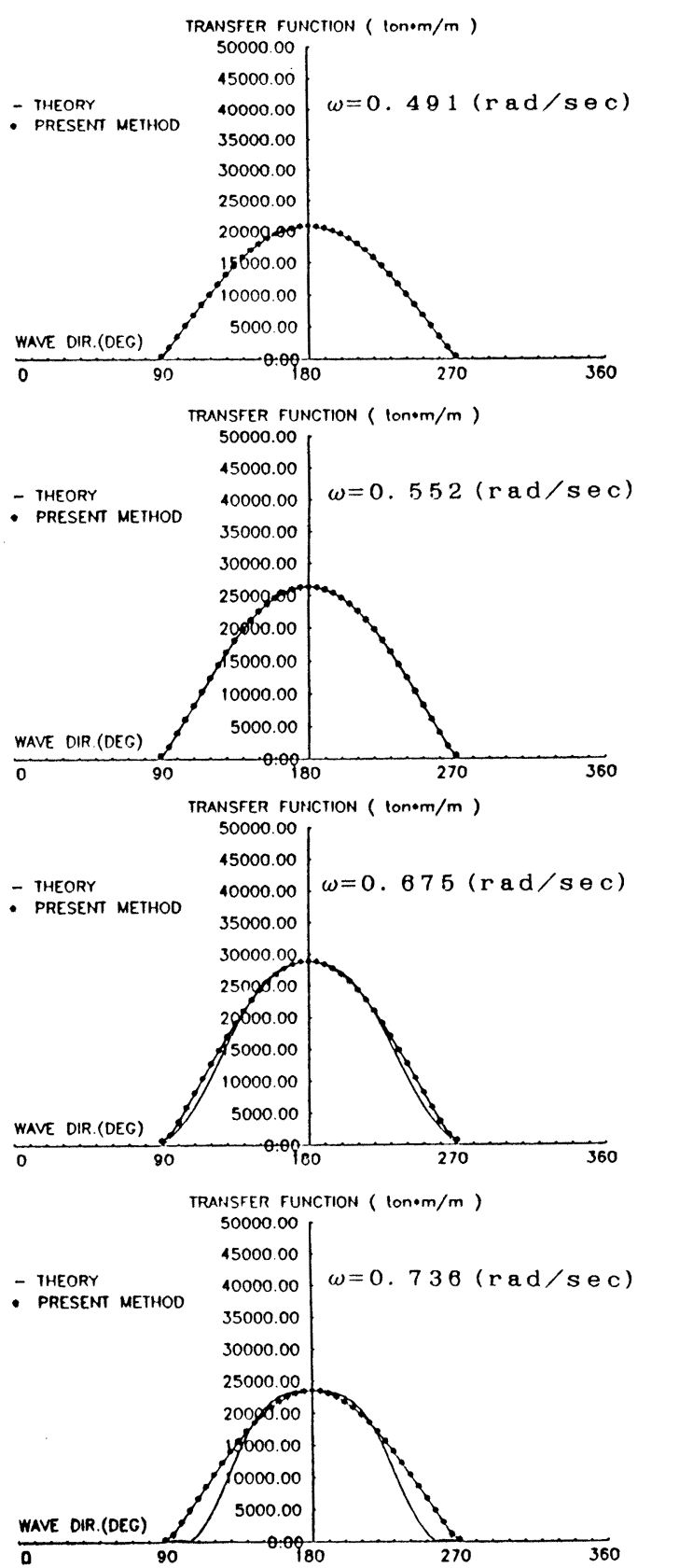

Fig. 9 Directional distribution of transfer functions of pitch wave exciting moments (The theoretical values were used in the present method, direction of wave is $180^{\circ}$, constraint points are $90^{\circ}$ and $180^{\circ}$.)
図 7 に示されたサージ波強制力は波の主方向に対して $\pm 45^{\circ}$ 程度の範囲で良い一致が示されている。この範囲で 本手法の精度は良いと言える。

図 8 に示されたヒーブ波強制力は, 横波方向の一致が得 られないために，主方向付近にも若干高目の值が示されて いる。これは推算に用いた関数が波方向角に対して高周波 成分を有さないために生じたものと考えられる。

ピッチ波強制モーメントに関する推算結果を図 9 に示 す。サージと同様に, 波の主方向に対して約 $\pm 45^{\circ}$ の範囲で 良い一致が確認される。

図 10,11 は, それぞれ, 実測デー夕, 理論計算デー夕に 基づく推算結果を横軸を周波数としてプロットした図であ る。*印が推定結果, 実線が理論值である。いずれも, 波 向角 $150^{\circ}$ での値である。理論デー夕による推算值が良い一 致を示していることにより, 本推算法の精度は高いものと 考えられる。従って, 前章で示した実測デー夕による推算 值が理論值と一致しない理由は, 本手法に起因するもので はないと言える。

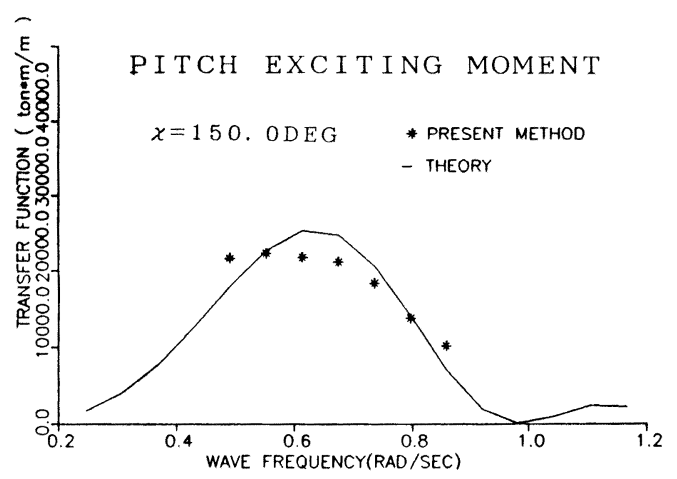

Fig. 10 Frequency distribution of transfer function of pitch exciting moment (The experimental datum were used in the present method)

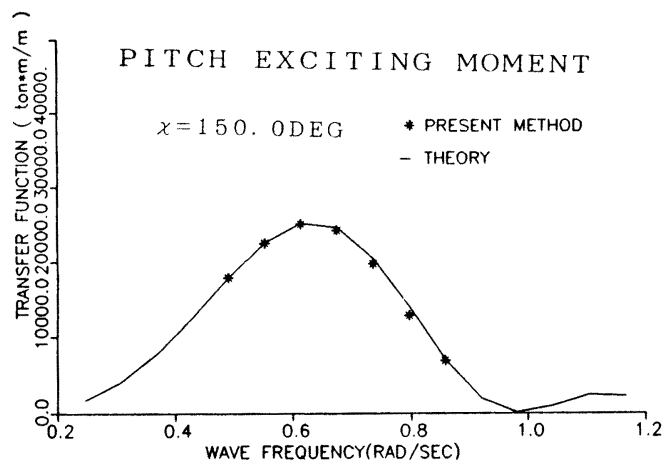

Fig. 11 Frequency distribution of transfer function of pitch exciting moment (The theoretical values were used in the present method) 


\section{2 高周波領域の精度と波の平均周期分布}

前章では主に波のパワーの存在する周波数領域の推算結 果を示した。さらに高周波数領域のおける推算精度と使用 した波の平均周期の分布範囲とに関する考察を加える。図 12 はピッチ波強制モーメントに関する, $\omega=0.859 \mathrm{rad} / \mathrm{s}$ の 周波数における応答関数である。理論值は実線で示されて いるように多峰状の関数である。推算值と理論值に一致す る範囲が波主方向に対し $\pm 30^{\circ}$ と狭いことが示されてい る。高周波成分を含む波を追加して推算を行った。使用し

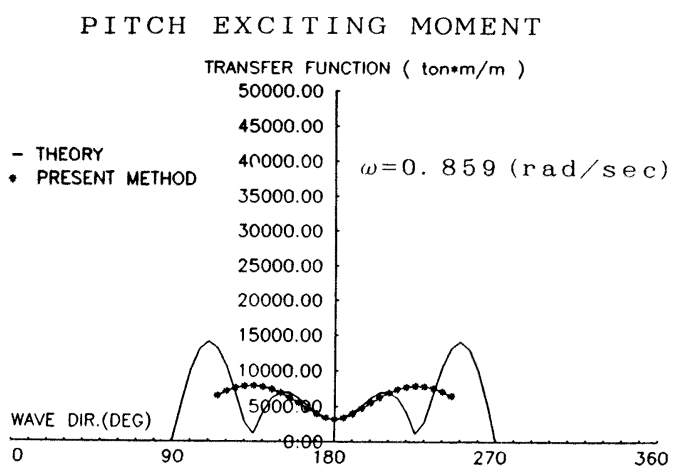

Fig. 12 Directional distribution of transfer functions of pitch wave exciting moment in high frequency

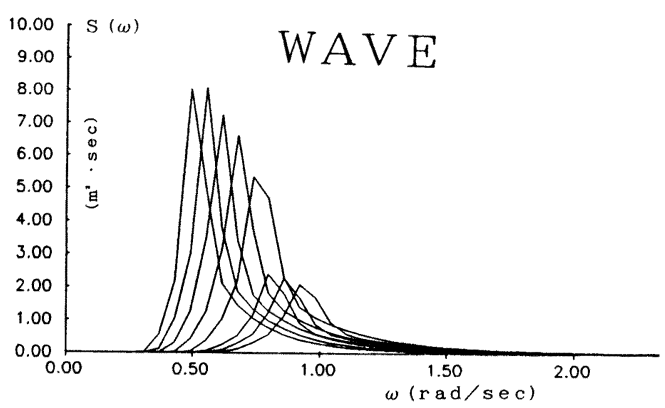

Fig. 13-a Spectral functions of directional wave (Theoretical values)

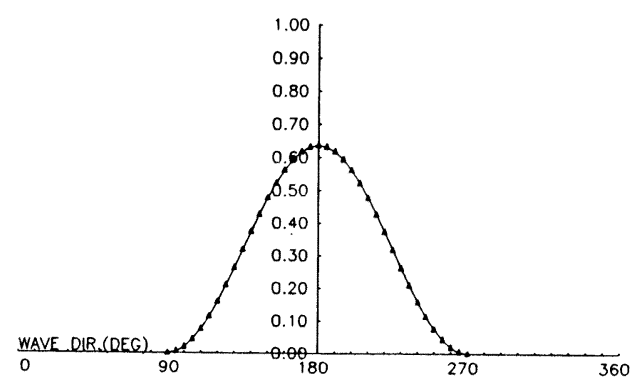

Fig. 13-b Mean directional distribution function of wave (Theoretical values)
た波は図 13 に示す 8 種類のスペクトル分布の波である。方 向分布は前例と同じ $\cos ^{2}$ 分布である。推算結果を図 14 に 示す。改善はされるものの, 図 12 と比べて著しい差はない。

この周波数領域での改善が要求されれば他の対策をとる 必要がある。しかし，応答関数も入射される波のパワーも 共に低い領域であるために, 対象とした構造物に与える影 響は少ないと考えられる。従って, 前章で用いた波の周波 数領域は妥当なものであり, 本手法はその領域での海洋構 造物の波強制力を推算するに十分な精度を有していると言 える。

\section{3 拘束条件と波の主方向の関係}

本手法は過渡水波の実験デー夕を用いて推算関数の拘束 条件として使用している。波の主方向の異なる波を入射す ることによりこの拘束点を取り除くことの可能性について 検討を加えた。理論計算によるデー夕を用いて，波の主方 向が向い波と横波の 2 種類のデー夕により推算を行った。

図 15，16 は，それぞれ，ピッチ波強制モーメントとヒー ブ波強制力の応答関数である。拘束条件は $180^{\circ}$ のみに減ら し，使用するデー夕を 2 種類の波主方向に増やした推算結 果である。前者の場合は図 9 で良好な推算結果を示してい たのに対して, 図 15 では横波付近での精度が低下してい る。一方, 後者では図 8 で一致しなかった範囲で改善され ていることが確認できる。両者の違いは応答関数のレベル にある。図 15 のように応答レベルの低い領域では拘束条件 が必要であり, 逆に, 図 16 のようにレベルの高い領域では 波の主方向が異なる波によるデータがあれば，拘束がなく ても精度を上げることができる。応答関数のレベルの低い 図 15 の例では取り除いた拘束条件は自明の 0 であるため, 拘束条件が必要となる点は実験ケース数に影響しないこと は明らかである。この結果より，全方向に対してレベルの 差が小さいヒーブは異なる波主方向のデー夕を必要とし， 一方，方向に対するレベルの差が多いサージ，ピッチ等は 自明の拘束点を有効に使用することで精度を上げることか゚ できると言える。

PITCH EXCITING MOMENT

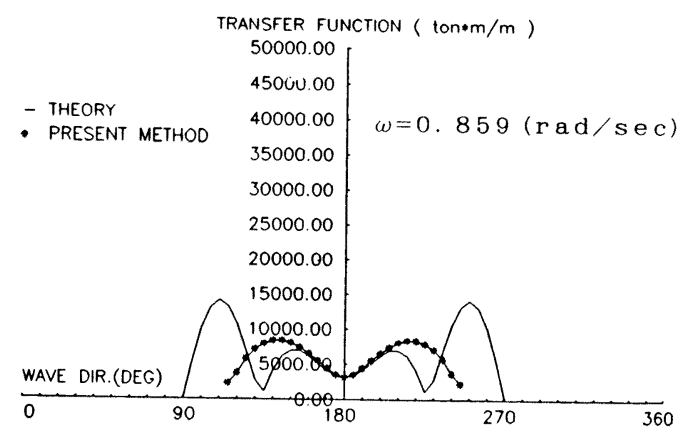

Fig. 14 Directional distribution of transfer functions of pitch wave exciting moment in high frequency 


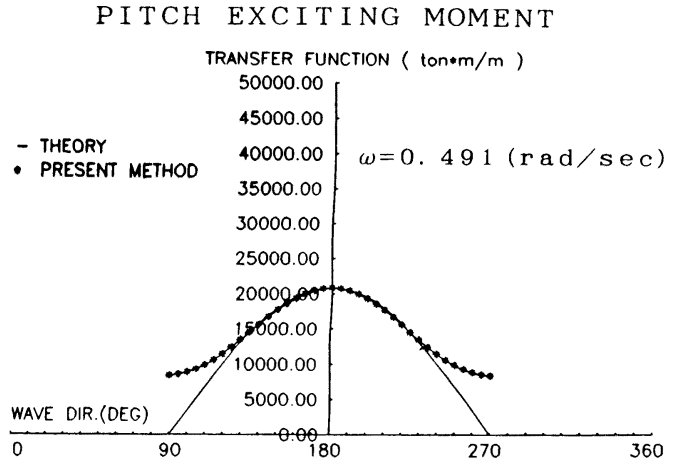

Fig. 15 Directional distribution of transfer function of pitch wave exciting moment (The theoretical values were used in the present method, directions of waves are $90^{\circ}$ and $180^{\circ}$, constraint point is $180^{\circ}$.)

HEAVE EXCITING FORCE

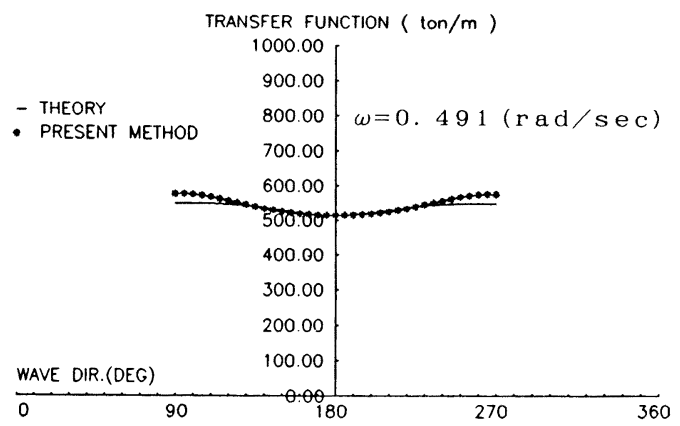

Fig. 16 Directional distribution of transfer function of heave wave exciting force (The theoretical values were used in the present method, directions of waves are $90^{\circ}$ and $180^{\circ}$, constraint point is $180^{\circ}$.)

\section{6. 方向分布関数の波強制力に与える影響}

本章では海洋構造物に方向スペクトル波が入射した時に 作用する波強制力について, 波の主方向と方向分布がどの ような影響を及ぼすかを調べる。

図 17 にはヒーブ波強制力の方向周波数応答関数の理論 值が示されている。波向角が $90^{\circ}$, 周波数が $0.981 \mathrm{rad} / \mathrm{s} に$ ピークが現れているが，この点は，この波周波数に対応す る波長とモデルの $y$ 方向の幅とが一致する場合に対応し ている。この点の影響が後述の図 18 のヒーブに現われるこ とになる。

方向スペクトル波中の波強制力の計算は図 17 に示され ているような波強制力の応答関数と波の方向スペクトルを 用いて, 式(1)により求めた。さらに波強制力の有義值は

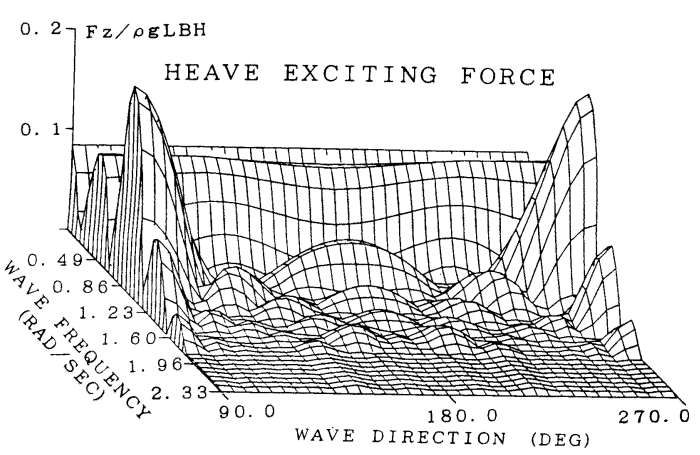

Fig. 17 Transfer function of heave wave exciting forces by Hooft method

その面積より推定した。そのような計算を各モードに対し て, 波の主方向を横波 $\left(90^{\circ}\right)$ から向い波 $\left(180^{\circ}\right)$ の範囲で 変化させて行った。このようにして求めた各モードの波強 制力の有義值を波の主方向に対してプロットした結果が図 18 に示されている。全ての結果は無次元化されている。使 用した波の方向分布関数は $\cos ^{2 s}(\chi / 2)$ なる表現をした時 の $s$ パラメータで $s=5, s=30, s=100$ の 3 種類の方向分 布を持つ波である。ここで, $s=100$ の波は長波頂波 $(s=\infty)$ を模擬した波である。尚, $\cos ^{2 n} \chi$ なる表現の $n$ とは $s \fallingdotseq$ $4.3 n$ なる関係がある。

図 18 に示されているように, 長波頂波中に比べ, 方向ス ペクトル波中ではその有義值が平滑になる傾向が見られ る。特に方向分布の広い $s=5$ の場合に, その傾向が強くな り, 例えば横波中のサージ波強制力とピッチ波強制モーメ ントの有義值の減少の程度は向い波中での $60 \%$ 程度にし かならない。これは方向分布が広くなれば主方向が有する 重みが小さくなるからである。尚, 波の主方向が $135^{\circ}, 225^{\circ}$ の付近では，どの波強制力も方向分布関数の違いによる差 がほとんどみられなくなり，ほほ同一値をとる。

文献 3 には本報と同じ手法で, 波の主方向が方向波中の 構造物の動摇の有義值に与える影響を調べた結果が示され ている。両者を比較すると, 傾向がよく一致していること が確認されるが，ヒーブに関して分布による影響は同じで あるが傾向に差が認められる。ヒーブの動摇は波の主方向 と方向分布関数の変化にあまり関係なく, 有義值がほとん ど一定であることに対して, 波強制力は横波中の有義值が 向い波中のものより $20 \%$ 以上大きくなることが示されて いる。それは図 17 に示されている波強制力の応答関数の波 向角が $90^{\circ}, 270^{\circ}$ でのピークがその有義値の計算に大きく 影響していることが原因と考えられる。

これらのことは海洋構造物の稼働性能や安全性能をより 正確に評価する際に，方向スペクトル波を考慮する必要が あることを示していると言える。 

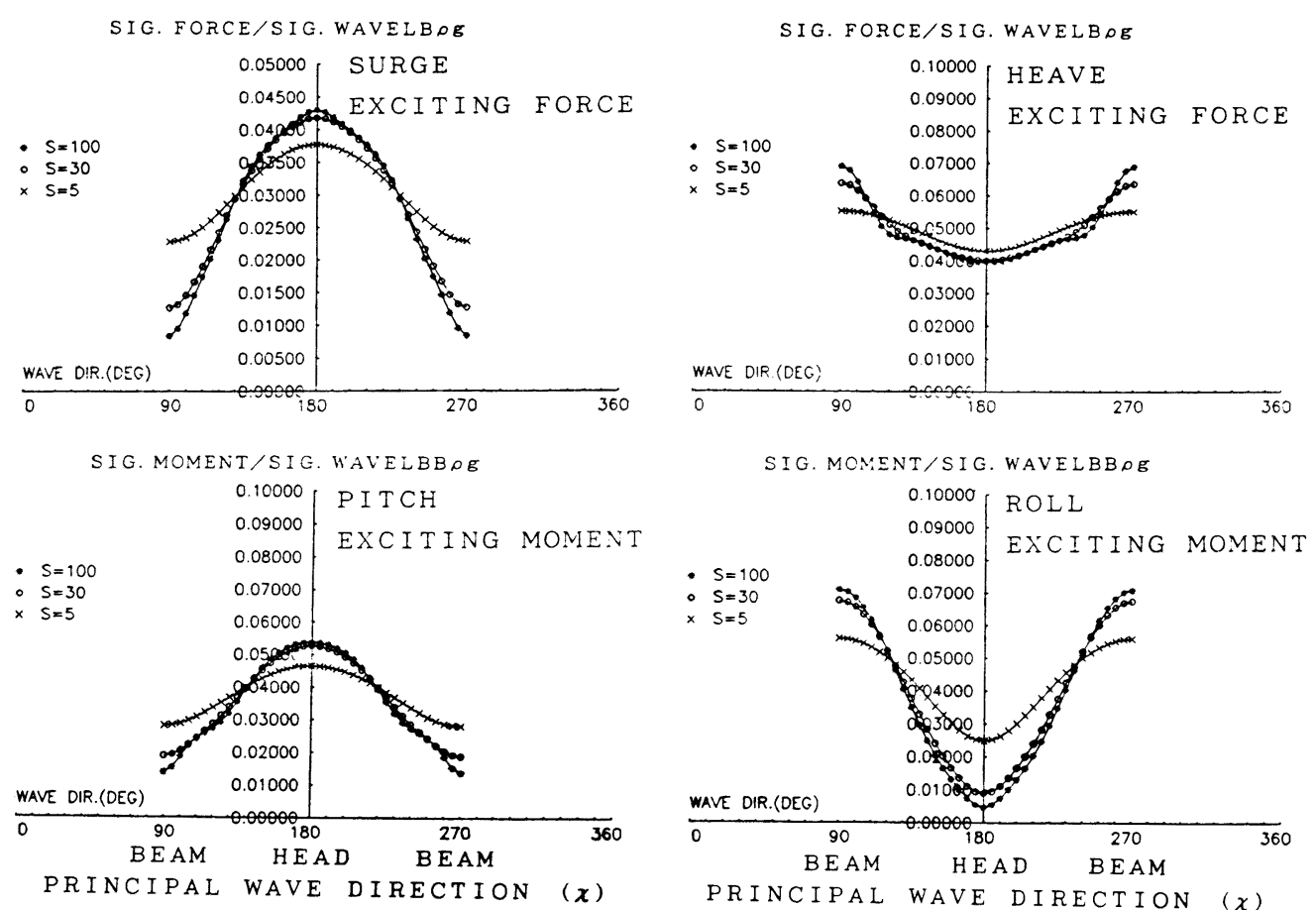

Fig. 18 The effect of wave spreading on short-term prediction of wave exciting forces for various principal wave directions

\section{7. 結}

本論では長水槽内で造波された方向スペクトル波中での 計測実験から，波周波数と波向角の関数として表現される 線形方向周波数応答関数を求める方法について, 前報 ${ }^{2)}$ 引続き線形波強制力に対して適用し，結果及びその精度を 検討した。結論を要約して，以下に示す。

1. 本論で示した方法によると主方向が 1 方向の比較的 少数の方向スペクトル波中の実験結果のみから，波強制力 の方向周波数応答関数が，約 $\pm 45^{\circ}$ の範囲で精度良く求ま ることが確認された。

2. 構造物に影響を与える周波数範囲の推算に使用した 方向波の平均周波数分布は本報で示した程度で十分である ことが確認された。

3. 自明な拘束条件を有効に用いれば，長波頂波により 実験で求めた拘束条件を加える必要がなくなり，実機でも 本方法を用いて方向周波数応答関数を求めることが原理的 に可能であることが確認された。

4. 波強制力の有義值の波主方向に依存する割合は波の 方向分布が広がることにより減少する。これは見方を変え ると長波頂波では小さい有義値となる方向でも主方向が同 じである広い方向スペクトル波中での有義值は逆に值が大
きくなるため注意する必要がある。<smiles>[Mg]</smiles>

実験及び解析にあたって本学の宮川清氏, 高山武彦氏に は御尽力頂いた。また, 平成 2 年度の当研究室海洋構造物 チームの卒業研究学生諸君にも御助力頂いた。合わせて謝 意を表する。

\section{参 考 文 献}

1）竹沢誠二, 平山次清, 上野誠也, 陳剛：浮遊型海洋 構造物の方向スペクトル波中実験に基く方向周波数 応答関数推定, 日本造船学会論文集, 第 168 号, (1990).

2）竹沢誠二, 平山次清, 上野誠也, 陳剛：浮遊型海洋 構造物の方向スペクトル波中実験に基く方向周波数 応答関数推定 (その 2), 日本造船学会論文集, 第 169 号, (1991).

3）竹沢誠二, 小林䫓太郎：方向スペクトル波中におけ る海洋構造物の応答一その 1 線形一次応答一, 日本 造船学会論文集, 第 165 号, (1989).

4）竹沢誠二, 酒井敏夫：波浪中の浮遊式海洋構造物に 作用する流体力および運動について，日本造船学会 論文集，第 147 号 (1980).

5）竹沢誠二, 平山次清, セルソ・カズュキ・モロオカ： 係留された半没型海洋構造物の波浪中運動の実用計 
算法, 日本造船学会論文集, 第 155 号, (1984).

6) Takezawa, S., Hirayama, T., Acharyya, S., 'Towed Ship Motion Test in Directional Spectrum Waves in a Long Tank (Part 3)', Journal of the Society of Naval Architects of Japan, Vol. 167, (1990).

7) Jefferys, E. R. et. al., 'Measuring Directional Spectra with the MLM', Conference on Direc- tional Wave Spectra Application, (1981).

8）竹沢誠二, 平山次清, 宮川清, 高山武彦: 長水槽用 方向スペクトル波発生装置, 関西造船協会誌, 第 211 号, (1989).

9）竹沢誠二, 宮川清, 高山武彦, 板橋正泰 : レーザ光 線群による方向スペクトル波計測, 日本造船学会論 文集, 第 166 号, (1989). 